\title{
Developing Multimedia-Based Learning Media for Basic Skill of Teaching Material in Order to Equip Professional Teachers
}

\author{
https://doi.org/10.3991/ijet.v16i07.21203 \\ Nurul Ratnawati ${ }^{(凶)}$, Neni Wahyuningtyas, I Nyoman Ruja, \\ M. Mujtaba Habibi, Rista Anggraini \\ Universitas Negeri Malang, Malang, Indonesia \\ nurul.ratnawati.fisdum.ac.id \\ Hery Yanto The \\ Zhejiang Yuexiu University of Foreign Languages, Shaoxing, China
}

\begin{abstract}
Learning media is quite important to be used by teachers in learning process. Through the media, teacher can easily deliver lessons, and in the other hand the media helps student comprehend lessons easily. Even more, media encourages student's independence in learning. This research aims to produce a multimedia-based learning media, lectora, for basic skill of teaching lesson. The research is conducted to students of Social Science Education Major who joined Social Studies Micro Teaching Class in June-September 2019. In developing the product, researcher used ADDIE developing model. Data in this research is quantitative, in form of assessment by validator. Meanwhile, qualitative data is in the form of suggestion and comments by material and media expert validator. The result of all validation is a multimedia-based learning media, lectora, for basic skill of teaching lesson, which is appropriate and interesting to use and share to others
\end{abstract}

Keywords — Learning media, multimedia, basic skills of teaching

\section{Introduction}

Universitas Negeri Malang as a teaching institute is trusted by government to shape and provide teachers with good quality. In teacher education, student is endowed in two aspects: content knowledge and pedagogy knowledge. Content knowledge is the ability to master material broadly and deeply which enables students to meet the specified competency standards [1]. Pedagogy knowledge is the ability to manage learning and teaching skills [2]. Both of these fields must be mastered by students to become a professional teacher. Professional teachers will be manifested in the form of mastery of skills, knowledge, and professional attitudes in carrying out their duties and functions as teachers [3].

There are many courses provided to achieve this, one of which is micro teaching. Preservice teachers' (PSTs) aims to enable candidate teachers to be able to develop 
teaching competencies by teaching in the classroom in public schools, understand the course program, evaluate the textbooks, carry out assessment and evaluation, and share the experiences gained during practice with his friends and application instructor [4]. Following this quote, micro teaching allows students as prospective teachers to develop their basic teaching competencies, carry out assessments, and other skills. Micro teaching encourages teachers to think about every detail of the lesson and allows teachers to practice various teaching techniques [5]. Besides, micro teaching is the most effective way to increase the professionalism of prospective teachers [6]. The purpose of micro teaching in general is to train and prepare students as prospective teachers in facing real teaching jobs [7].

However, the experience of researchers when teaching micro teaching subjects in the social studies field of students has not been able to properly practice basic teaching skills. Asril also stated that according to observations the ability and skills of students as prospective teachers in teaching practice were still weak [8]. Many of them still have difficulty practicing basic teaching skills. This is because they generally lack self-confidence and do not master the material [9]. Also, they only receive theoretical knowledge without any practice and then immediately implement it in school internships [10]. Self-efficacy also affects a person's fighting power to master all the knowledge and skills required for effective learning [11].

After knowing that there are still many students who have not been able to practice, one of the strategies applied is to ask students to make observations to schools to see how the teacher teaches from beginning to end. The results were good, namely training students to do a small research. The benefits of doing mini research are that students have a strong understanding of a concept, solve problems creatively, provide real experiences, and hone other skills [12].

However, based on the researcher's experience, this strategy has a weakness, namely when not all subjects require to go to the field while there are subjects that have to go to the field, it causes student schedules to be out of sync. This means that sometimes they have to stay on campus for some courses, but the allotted time for observation continues. So that the observation time seems short, even though in reality it is given a long time to practice in the field. The second weakness, not all schools can be used as a place of observation, so students have to look for other alternatives. The next weakness is that it cannot be denied that the time needed to make observations is long, from handling letters to arranging schedules at school.

Reflecting on the experience above, this is where the urgency of this research is carried out. Researchers have innovative ideas that are effective and efficient to support micro teaching subjects in the social studies field of study by making multimedia-based learning media lectora in which there are real videos of the learning process in class about basic teaching skills. So the technique of delivering information in multimedia combines information in the form of text, graphics, images, sound, images, and videos. Videos can be very effective learning tools [13]; [14]. By looking at the text, images, and videos packaged in multimedia, it is hoped that students can better understand and animate when doing micro-learning practices. 
Several research results show the benefits of using multimedia. First, the learning process with the help of multimedia becomes more interactive, effective, efficient, interesting, and can foster learning motivation [15]. Second, it can overcome the limitations of space and time and clarify the presentation of the message [16]. Third, the use of multimedia can facilitate and improve learning efficiency so that learning objectives can be achieved [17]. Fourth, the use of multimedia allows students to adjust the speed of learning independently [18]. Fifth, using multimedia can help students to repeat lessons that are not understood anytime and anywhere [19]. Sixth, the use of multimedia can present phenomena clearly and simulate complex content [20]. Therefore, this study intends to develop multimedia to equip students with basic teaching skills so that they become professional teachers.

\section{Method}

This research produces a product in the form of multimedia-based learning media lectora on the basic skills of teaching. The product specifications contained in this media are 1) teaching materials on planning and implementation stages of micro-teaching and 2) video of the stages of learning activities, namely the opening, core, and closing and what must appear in the three activities are skilled basic in micro teaching such as skills to provide reinforcement, managing classes, asking questions, explaining, and so on.

\subsection{Research procedure}

The research method used in this research is research and development with the ADDIE (Analyze-Design-Development-Implementation-Evaluation) model. This model is a learning design model that shows simple and easy-to-learn design stages. Sukenda explained that this model uses 5 stages of development [21], namely: first, analyze, the analysis stage is a needs assessment process, identifying problems (needs) or analyzing the need for development. After the needs analysis, the next step is to analyze the feasibility and requirements for developing the learning media application. The output produced at this stage is a problem and the researcher proposes a solution to solve the problem, namely in the form of product preparation.

Second, design. The design is based on what has been formulated in the analysis stage. The design stage is analogous to designing teaching and learning activities. This activity is a systematic process that starts from setting learning objectives, designing scenarios or teaching and learning activities, and designing learning materials. The design of this learning media feature is still conceptual and will underlie the next development process. The essence of the activity at this stage is to design the concept of learning media application products on paper. The design is written for each learning unit. Instructions for implementing the design or manufacture of the product are written in detail. Third development. This stage is the stage of production where everything that has been made in the design stage becomes real or the realization of the design of learning media products. Then validate the media and material experts. 
Fourth implementation. At this stage, the learning media is ready for use by students. Get started with using a new product in real learning or environment. The activities carried out in this stage are to prepare and market them to target students. After implementing the learning media application, an initial evaluation is carried out to provide feedback on the application of the next learning media application. Fifth evaluation. Evaluation is carried out after testing the application of the whole learning media is complete. The results of the evaluation are used to provide feedback to the users of learning media. Revisions are made following the results of the evaluation or the needs that have not been fulfilled by the learning media application.

\subsection{Type of data}

The types of data in this study are quantitative and qualitative. Validator's criticism and suggestions include qualitative data. Meanwhile, the calculation of the average score of the questionnaire filled out by the validator includes quantitative data.

\subsection{Data analysis}

The data analyzed were the results of a questionnaire that had been filled in by media and learning material experts. The formula for calculating it is as follows.

$$
\mathrm{P}=\frac{f}{n} \times 100 \%
$$

Information:

$\mathrm{f}=$ frequency

$\mathrm{n}=$ the maximum number of frequencies

$\mathrm{P}=$ percentage

Table 1. Product Validity Assessment Criteria

\begin{tabular}{|c|l|}
\hline Questionnaire Score & \multicolumn{1}{c|}{ Criteria } \\
\hline $90 \%-100 \%$ & Very good to be used and shared (needs little revision) \\
\hline $80 \%-89 \%$ & Good to be used and shared (needs revision) \\
\hline $70 \%-79 \%$ & Good enough to be used and shared (needs more revision) \\
\hline $60 \%-69 \%$ & Not good to be used and shared (needs a lot of revision) \\
\hline$\leq 59 \%$ & Not qualified to be used and shared \\
\hline
\end{tabular}




\section{Result and Discussion}

\subsection{Analysis stage}

Based on the results of the needs analysis by distributing questionnaires to students, it was found that $73 \%$ of students stated that the basic concept of teaching material was important but difficult to understand if only by reading the material and $55 \%$ of students answered that they did not have a real picture of various basic teaching skills. Thus, it is necessary to design multimedia-based learning media on basic teaching skills as a solution to overcoming these problems.

\subsection{Design stage}

At this stage, the researcher designed the concept of learning media products based on multimedia lectora on the basic skills of teaching. Researchers design each component in this product in details. The components are cover page with various color and font, home menu consisting of introduction, aims, learning material, references, and developer. Each home menu has materials in sync with the title. Exit navigation button is also pasted there, as well as background music (see figure 1). Introduction page (see Figure 2), has navigation buttons to exit from the media or go back to home menu page, as well as background music button.

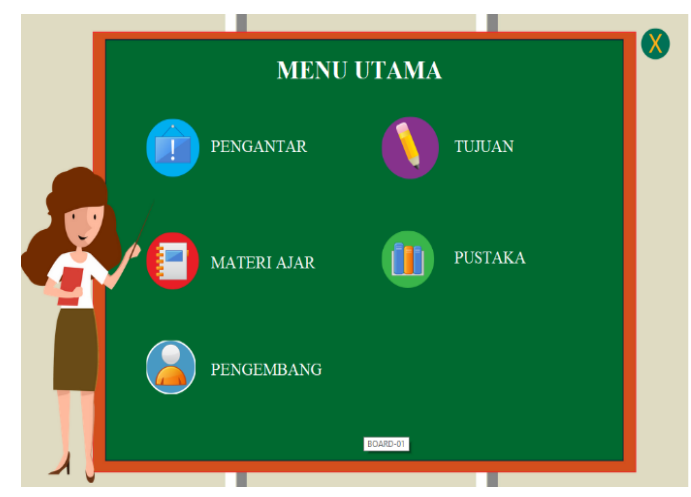

Fig. 1. Home Menu Interface 


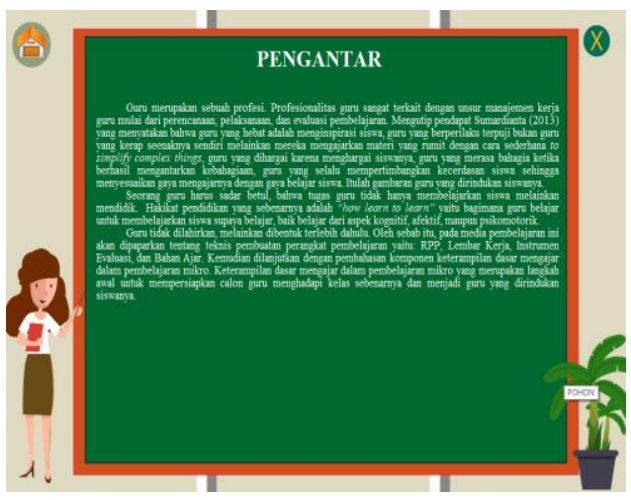

Fig. 2. Introduction Interface

There is also lesson aims option to access easily purposes and content of presented material. Learning with this media aims two things, that is to understand mechanism of making learning media and to understand components of basic skill of teaching. In this option, it has navigation buttons to exit from the media or go back to home menu page, as well as background music button (see Figure 3). Lesson material menu has two options (see Figure 4), which are mechanism of making learning media and components of basic skill of teaching. Mechanism of making learning media material discusses learning devices with examples as well, such as $R P P$ (lesson plan), $L K P D$, teaching material, and evaluation instrument (see Figure 5). Components of basic skill of teaching material discusses seven skills in teaching (see Figure 6). Each component is provided with relevan practical videos (see Figure 7). In this menu, navigation buttons to exit from the media or go back to home menu page, as well as background music button are provided. Next menu is references and developer profile.

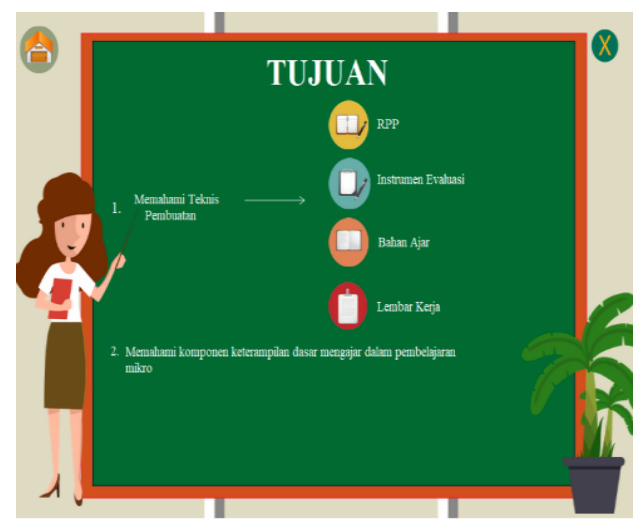

Fig. 3. Lesson Aim Menu 


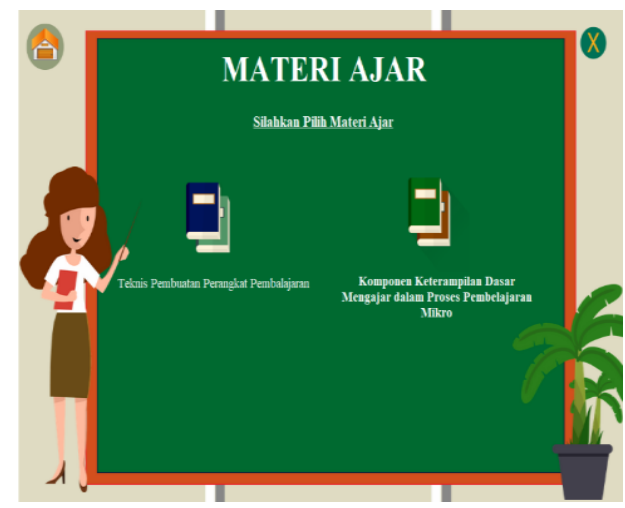

Fig. 4. Lesson Material Menu

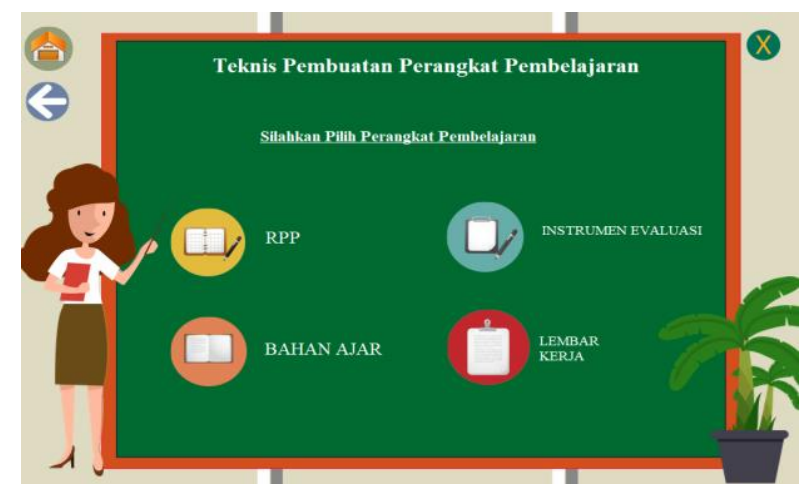

Fig. 5. Mechanism of Making Learning Media Material Menu

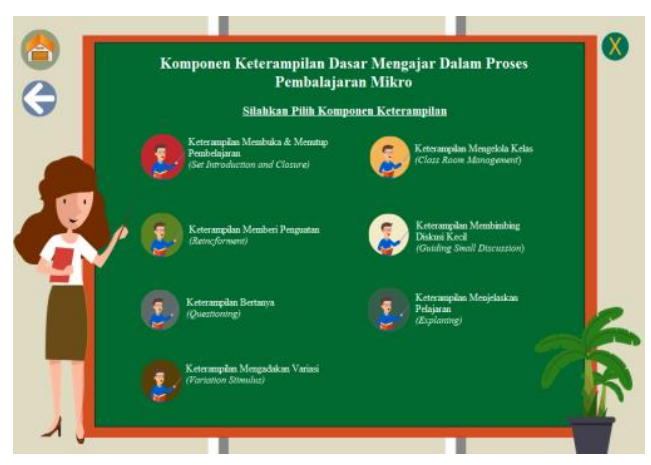

Fig. 6. Seven Skills in Teaching Material Menu 


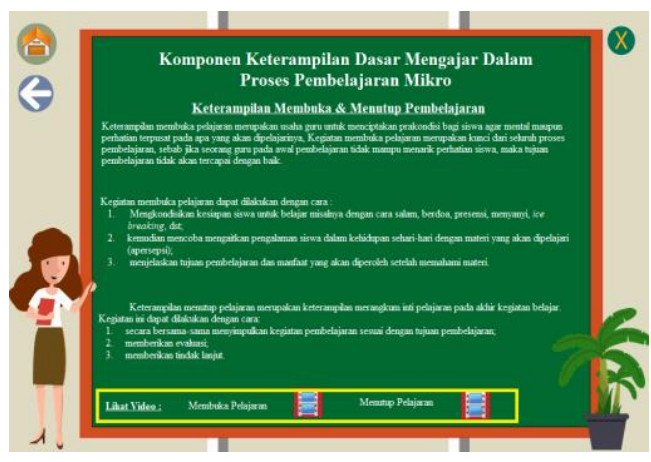

Fig. 7. Relevant video menu for a component in Seven Skills in Teaching Material

\subsection{Development stage}

The material expert validator in the development of multimedia-based learning media Lectora is a social studies lecturer at UIN Maulana Malik Ibrahim Malang. The suggestions given by the validator are fixing sentences that are ineffective or too long, improving typography, and adding concrete examples in the material. The results of the validation assessment by material experts after the revision are shown in Table 1. Overall the products produced are very good or very suitable for use and can be disseminated with an average of $97 \%$.

Table 2. Validation Score Summary from Material Experts after Revision

\begin{tabular}{|c|l|c|}
\hline No. & \multicolumn{1}{|c|}{ Indicator } & Percentage \\
\hline 1. & Material organization/presentation of material & $95 \%$ \\
\hline 2. & The suitability of the material with the learning outcomes of the course & $100 \%$ \\
\hline 3. & Material accuracy & $96 \%$ \\
\hline 4. & Depth of material & $98 \%$ \\
\hline 5. & The contextuality of the material & $100 \%$ \\
\hline 6. & Encourage curiosity & $95 \%$ \\
\hline 7. & Presentation of material Average & $95 \%$ \\
\hline 8. & Language & $95 \%$ \\
\hline \multicolumn{2}{|c|}{} & $97 \%$ \\
\hline
\end{tabular}

The material expert validator in developing multimedia-based learning media Lectora is a lecturer in Educational Technology, Universitas Negeri Malang. The suggestions given by the validator are improving the back sound, improving the cover design, and harmonizing the writing and background so that the writing is clearer. The results of the validation assessment by media experts after the revision are shown in Table 2. Overall the products produced are very good or very attractive to use and can be disseminated with an average of $96 \%$. 
Table 3. Validation Score Summary from Media Experts after Revision

\begin{tabular}{|c|l|c|}
\hline No. & \multicolumn{1}{|c|}{ Indicator } & Percentage \\
\hline 1. & Graphic propriety & $96 \%$ \\
\hline 2. & Content display & $100 \%$ \\
\hline 3. & Layout harmony & $94 \%$ \\
\hline 4. & Layout accomplishment Average & $95 \%$ \\
\hline \multicolumn{2}{|c|}{ Ave } \\
\hline
\end{tabular}

\subsection{Implementation and evaluation stage}

The implementation stage was to test the effectiveness of instructional media carried out on 38 students of 2018 State University of Malang offering A. The mean results from the analysis of the effectiveness of the value were $86 \%$ with good criteria. The following is a table of the results of student responses to multimedia effectiveness.

Table 4. Results of Student Responses to Multimedia Effectiveness

\begin{tabular}{|c|c|c|c|c|c|c|}
\hline Aspect & A & B & C & D & E & \\
\hline $\begin{array}{c}\text { The Effective- } \\
\text { ness of Learning } \\
\text { Media }\end{array}$ & $\begin{array}{c}\text { Learning ob- } \\
\text { jectives } \\
\text { achieved }\end{array}$ & $\begin{array}{c}\text { Overcoming } \\
\text { the limita- } \\
\text { tions of space } \\
\text { and time }\end{array}$ & $\begin{array}{c}\text { Interactive } \\
\text { and interest- } \\
\text { ing }\end{array}$ & $\begin{array}{c}\text { Set the pace of } \\
\text { learning inde- } \\
\text { pendently }\end{array}$ & $\begin{array}{c}\text { Simulate } \\
\text { complex con- } \\
\text { tent }\end{array}$ & Average \\
\hline Percentage & 88 & 87 & 85 & 85 & 86 & $86 \%$ \\
\hline
\end{tabular}

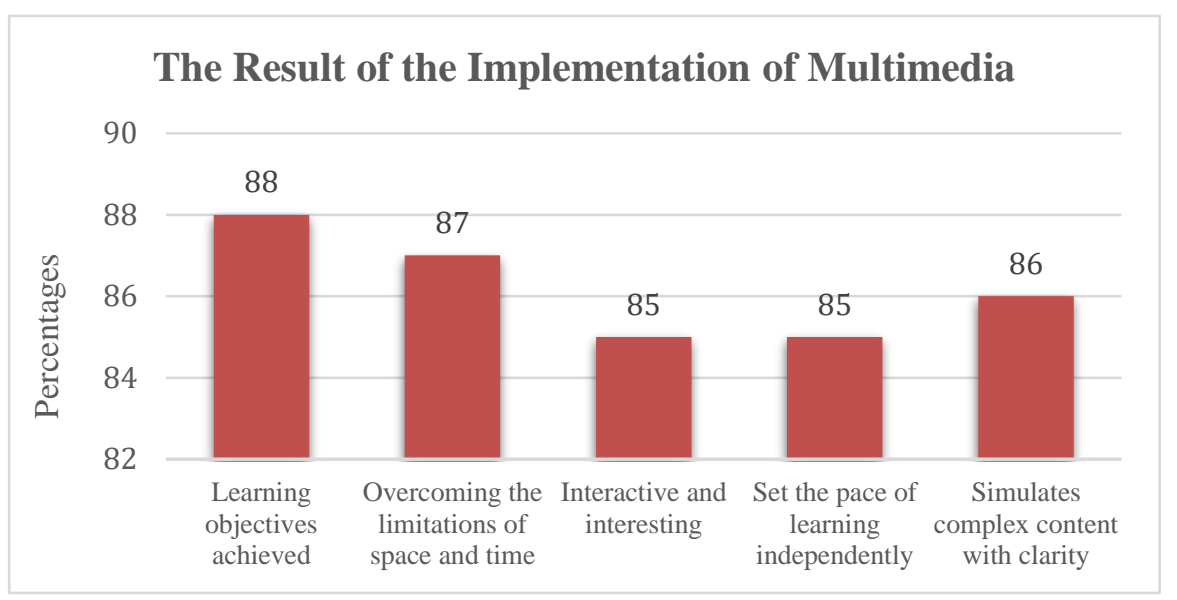

Fig. 8. The Results of the Implementation of Multimedia

The percentage of the assessment shows that the media is very effectively used by students so that learning objectives are achieved, overcoming space and time limitations, being interactive and able to motivate, adjusting learning speed independently, 
and being able to simulate complex content. Besides, this media contains clear instructions so that it is easy to use.

\subsection{Discussion}

Teachers are essentially a profession. Professionalism is a need that cannot be delayed anymore, the increasing competition is getting tougher in the era of globalization, the professionalism of a teacher needs to be improved [22]. Teacher professionalism is closely related to the elements of teacher work management from planning, implementing, and evaluating learning. Good lesson planning facilitates the implementation of learning, the achievement of learning objectives, and facilitates the evaluation of learning [23]. The estuary of a teacher's professionalism is the realization of quality learning.

One alternative in the effort to produce professional teachers is through micro teaching. This learning aims to train prospective teachers with students' conditions, materials, and time that have been arranged in such a way as to provide a feeling of comfort for prospective teachers to practice teaching [24]. The content in micro teaching is basic teaching skills. There are several elements of basic teaching skills consisting of questioning skills, reinforcing skills, variation skills, explanation skills, opening and closing lessons, guiding small group discussion skills, class management skills, and small group and individual explaining skills. Coupled with supporting content for learning planning in the form of learning tools. Learning tools consist of, lesson plans, worksheets, teaching materials, learning media, and assessment instruments [26]. This content is very complex, so it needs to be simplified, made as effective as possible so that it is easily understood by students as prospective teachers.

One alternative that can be taken is to package the material in learning media. The learning media chosen is multimedia based on lectora. Lectora is an electronic learning development (e-learning) software that is relatively easy to apply [27]. Lectora is included in a group or type of multimedia because it can combine several media such as flash, video, audio, visual [28]. Learning media developed using Lectora Inspire can be published online and offline. Here are some of the advantages of Lectora Inspire: 1) teaching materials can be made without programming. 2) The types of evaluation provided are various, namely test forms such as multiple-choice, true/false, matching (matching), drag and drop short fill (fill in the blank), and hot spot. 3) Can be accessed both offline and online. 4) Able to use text, sound, video, animation in one unit. 5) Able to visualize abstract material [29].

As it is known, the creative use of multimedia can improve learning efficiency so that learning objectives can be achieved. But the use of multimedia as a medium. Multimedia should be viewed as a complement to teaching, not as a substitute for a role [30].

\section{Concussion}

Based on the validation results of the material and media expert validators, as well as the effectiveness test, the multimedia-based learning media lectora on the resulting 
basic teaching skills material is valid and very feasible to use. The revisions that have been made after the trial are expected to improve the quality of the media being developed. Multimedia-based learning media is a practical alternative to answer the problems of limited space and time, unclear practice material, and the absence of real examples of basic teaching skills. So that with the presence of this media it is hoped that learning can run effectively and efficiently.

\section{$5 \quad$ References}

[1] A. Dudung, "Kompetensi Profesional Guru," Jurnal Kesejahteraan Keluarga dan Pendidikan (JKKP), vol. 5, no. 1, hlm. 9-19, 2018. https://doi.org/10.21009/jkkp.051.02

[2] W. B. Sulfemi dan A. H. Lestari, "Korelasi Kompetensi Pedagogik Guru dengan Prestasi Be-lajar Mata Pelajaran IPS di SMP Muhammadiyah Pamijahan Kabupaten Bogor," Jurnalll-miah Edutecno, vol. 16, no. 1, 2017. https://doi.org/10.31227/osf.io/7j3pr

[3] C. Fitriani, M. Ar, dan N. Usman, "Kompetensi Profesional Guru dalam Pengelolaan Pembelajaran Di MTs Muhammadiyah Banda Aceh,” Jurnal Magister Administrasi Pendidikan, vol. 5, no. 2, hlm. 8, 2017.

[4] H. B. Memduhoğlu, N. Kotluk, dan A. Yayla, "The Effect of Focus Group Discussions on Pre-service Teachers' Teaching Experiences and Practices: A Mixed Methods Study," INT J INSTRUCTION, vol. 10, no. 4, page. 273-292, Okt 2017. https://doi.org/10.12973/ iji.2017.10416a

[5] G. Zhou, J. Xu, dan D. Martinovic, "Developing Pre-service Teachers' Capacity in Teaching Science with Technology Through Microteaching Lesson Study Approach," EURASIA J MATH SCI T, vol. 13, no. 1, Okt 2016. https://doi.org/10.12973/eurasia.2017.00605a

[6] Z. Arsal, "The Effects of Microteaching on the Critical Thinking Dispositions of Pre-service Teachers," AJTE, vol. 40, no. 40, Jan 2015. https://doi.org/10.14221/ajte.2014v40n3.9

[7] M. Ardi, "Pelaksanaan Pembelajaran Micro Teaching bagi Mahasiswa Program Studi PPKn STKIP-PGRI Pontianak," Jurnal Edukasi, vol. 1, no. 1, hlm. 10, 2014.

[8] Z. Asril, Micro Teaching Disertaidengan Pedoman Pengalaman Lapangan. Depok: PT. Raja GrafindoPersada, 2013.

[9] E. T. Sulistyo, "Kendaladalam Pembelajaran Micro Teaching dan Pemecahannya," JurnalInovasi Pendidikan, vol. 11, no. 1, hlm. 8, 2010.

[10] Y. Olensia, "Analisis Pelaksanaan Micro Teaching Calon Guru Kimia Di FITK UIN Raden Fatah Palembang," OJPK, vol. 2, no. 2, hlm. 58-70, 2018, https://doi.org/10.19109/ ojpk.v2i2.2850

[11] S. R. Chesnut dan T. A. Cullen, "Effects of Self-Efficacy, Emotional Intelligence, and Perceptions of Future Work Environment on Preservice Teacher Commitment," The Teacher Educator, vol. 49, no. 2, page. 116-132, Apr 2014. https://doi.org/10.1080/08878730. 2014.887168

[12] N. Ratnawati dan I. Idris, "Improving Student Capabilities through Research-Based Learning Innovation on E-Learning System," Int. J. Emerg. Technol. Learn., vol. 15, no. 04, page. 195, Feb 2020. https://doi.org/10.3991/ijet.v15i04.11820

[13] R. H. Kay, "Exploring the use of video podcasts in education: A comprehensive review of the literature," Computers in Human Behavior, vol. 28, no. 3, page. 820-831, Mei 2012. https://doi.org/10.1016/j.chb.2012.01.011

[14] W. J. Hsin dan J. Cigas, "Short Videos Improve Student Learning in Online Education," Journal of Computing Sciences in Colleges, 2013. 
[15] S. T. Rahmat, "Pemanfaatan Multimedia Interaktif Berbasis Komputerdalam Pembelajaran," Jurnal Pendidikan dan Kebudayaan Missio, vol. 7, no. 2, hlm. 13, 2015.

[16] Y. S. Maharani, "Efektivitas Multimedia Pembelajaran Interaktif Berbasis Kurikulum 2013," Indonesian Journal of Curriculum and Educational Technology Studies, vol. 3, no. 1, hlm. 10, 2015.

[17] I. D. Kurniawati dan S.- Nita, "Media Pembelajaran Berbasis Multimedia InteraktifuntukMeningkatkan Pemahaman Konsep Mahasiswa," Doubleclick, vol. 1, no. 2, hlm. 68, Feb 2018, doi: 10.25273/doubleclick.v1i2.1540.

[18] I. Nur Jannah, “Efektivitas Penggunaan Multimedia dalam Pembelajaran IPA di SD,” JISD, vol. 4, no. 1, hlm. 54, Apr 2020. https://doi.org/10.23887/jisd.v4i1.24135

[19] A. Kurniawti, F. Festiyed, dan A. Asrizal, "Analisis Efektifitas Multimedia InteraktifDa-lam Menghadapi Tantangan Pendidikan di Era Globalisasi Industri 4.0,” Jurnal Penelitian-Pembelajaran Fisika, vol. 5, no. 2, 2019.

[20] Iqbal Shah dan Muhammad Khan, "Impact of Multimedia-aided Teaching on Students' Academic Achievement and Attitude at Elementary Level," UCER-A, vol. 5, no. 5, Mei 2015. https://doi.org/10.17265/2161-623x/2015.05a.006

[21] K. Shelton dan G. Saltsman, "Using the Addie Model for Teaching Online". International Journal of Information and Communication Technology Education, vol. 2, no. 3, page. 1426, Jul 2006. https://doi.org/10.4018/jicte.2006070102

[22] M. Kristiawan dan N. Rahmat, "Peningkatan Profesionalisme Guru melalui Inovasi Pembelajaran," JurnalIqra': Kajian Ilmu Pendidikan, vol. 3, no. 2, 2018. https://doi.org/10. 25217/ji.v3i2.348

[23] N. S. Hanum, "Keefektifan E-Learning sebagai Media Pembelajaran (StudiEvaluasi Model Pembelajaran E-Learning SMK Telkom Sandhy Putra Purwokerto)," Jurnal Pendidikan Vokasi, vol. 3, hlm. 13, 2013. https://doi.org/10.21831/jpv.v3i1.1584

[24] A. Sadikin dan U. Yelianti, "PersepsiMahasiswaBiologiTerhadapPelaksanaanPembelajaranMikro," BIODIK: JurnalIlmiah Pendidikan Biologi, vol. 6, no. 1, 2020. https://doi.org/ $\underline{10.22437 / \text { bio.v3i1.4582 }}$

[25] F. S. Sundari dan Y. Muliyawati, "Analisis Keterampilan Dasar MengajarMahasiswa PGSD,” PedagogJIP, vol. 1, no. 1, hlm. 26-36, Apr 2017. https://doi.org/10.33751 /pedagog.v1i1.225

[26] A. Fatmawati, "PengembanganPerangkatPembelajaranKonsepPencemaranLingkunganMenggunakan Model Pembelajaran Berdasarkan Masalahuntuk SMA KELAS X," EduSains, vol. 4, no. 2, hlm. 10, 2016.

[27] M. S. Zuhri dan E. A. Rizaleni, "Pengembangan Media Lectora Inspire denganPendekatanKontekstual pada Siswa SMA Kelas X," PYTHAGORAS: Jurnal Program Studi Pendidikan Matematika, vol. 5, no. 2, hlm. 7, 2016, http://dx.doi.org/10.33373/pythagoras.v5i2.463

[28] E. Wahyuningsih dan A. Mustadi, "Pengembangan Multimedia Lectora Pembelajaran Tematik-Integratifuntuk Peningkatan Nilai Karakter Siswa Kelas IV Sekolah Dasar,” JPK, no. 1, Agu 2016. https://doi.org/10.21831/jpk.v0i1.10729

[29] N. D. Shalikhah, "Media Pembelajaran Interaktif Lectora Inspire sebagai Inovasi Pembelajaran," Warta, vol. 20, no. 1, hlm. 9-16, Jun 2017. https://doi.org/10.23917/warta.v19i3.2842

[30] A. Wijoyo, "Pengaruh Hasil Belajar Siswadengan Menggunakan Multi Media Pembelajaran Interaktif untuk Sekolah Menengah Pertama dan Sekolah Menengah Atas," JIUP, vol. 3, no. 1, hlm. 46, Mar 2018. https://doi.org/10.32493/informatika.v3i1.1519 


\section{$6 \quad$ Authors}

Nurul Ratnawati is a lecturer in the Social Studies Program, Faculty of Social Science, Universitas Negeri Malang, Indonesia. She is majoring in Social studies learning innovation and mastering in learning media and related information technology in education. nurul.ratnawati.fis@um.ac.id

Neni Wahyuningtyas is a lecturer in the Faculty of Social Science, Universitas Negeri Malang, Indonesia. She is majoring in Geography and mastering in learning media and related information technology in education.

I Nyoman Ruja is one of the lecturers in the Social Studies Program, Faculty of Social Science, Universitas Negeri Malang. He is interested in learning innovation.

Muhammad Mujtaba Habibi is a lecturer in the Pancasila and Citizenship Education Program, Faculty of Social Science Universitas Negeri Malang. He is majoring in Multimedia.

Rista Anggraini is a college student in the Social Studies program, Faculty of Social Science Universitas Negeri Malang. She is majoring in education and multiculturalism.

Hery Yanto The is a lecturer at the Zhejiang Yuexiu University of Foreign language, China. He is interested in innovative and creative instructional design. herythe@outlook.com

Article submitted 2021-01-19. Resubmitted 2021-02-27. Final acceptance 2021-02-28. Final version published as submitted by the authors. 